\title{
Prevalence of Teenagers with Disabilities in a Medium-Sized Municipality
}

\begin{abstract}
Evanira Rodrigues Maia1,2, Lorita Marlena Freitag Pagliuca3, Estelita Pereira Lima², Jucier Gonçalves Júnior ${ }^{2}$,
\end{abstract} Crístenes Sanches Lucena Gomes ${ }^{2}$, Paulo César de Almeida ${ }^{3}$

\section{Abstract}

Introduction: Despite variations in the beginning and the end, adolescence is the second decade of life, 10-19 years. According to the World Report on disability among those individuals aged 0-14 years of age, 93 million had severe or moderate disabilities and 13 million severe disabilities. Therefore, this study aimed to identify adolescents with hearing, visual and physical impairment.

Methods: A quantitative transversal study of a medium-sized municipality. Data was collected at interviews conducted by community health workers, with an instrument containing sociodemographic data and impairment characteristics. Data was organized in spreadsheets and analyzed for correlations between types of disabilities and other variables by chi-square test. Statistical significance was verified by a 0.05 level.

Results: Physical disability prevailed over visual and auditory. An association was found between disability and level of education ( $p=$ 0.023). Conclusion: Support and incentive education policies are necessary among the disabled.

\section{Keywords}

Disabled Persons; Health Public Policy; Adolescent Health; Adolescent.
1 Department of Nursing, University Regional of Cariri, Crato, Brazil.

2 Department of Medicine, University Federal of Cariri, Barbalha, Brazil.

3 Department of Nursing, University Federal of Ceará. Fortaleza, Brazil.

Contact information:

Lorita Marlena Freitag Pagliuca.

Address: Rua Alexander Baraúna, 1115, Rodolfo Teófilo, Fortaleza, CE, Brazil, 63180000.

Tel: $+055(85) 33668462$.

झ pagliuca@ufc.br

\section{Introduction}

Adolescence can be conceptualized from different perspectives: biological, psychological, legal and sociocultural. However, none of 
these alone are able to set this stage of human development [1]. Adolescence is the second decade of life, 10-19 years [2]. Despite variations in the beginning and the end, it is known that adolescence marks the transition into adulthood, both physically, and behaviorally.

Worldwide, there are over 500 million people with disabilities and their access to health systems are inadequate [3]. Machado, Scramin [4] it is known that $10 \%$ of people in developing countries, in times of peace, have a disability. Santos, Pequeno et al. [5] in relation to the distribution in Brazil, the existence of regional asymmetries and people with disabilities are found more often in the states of northeastern Brazil.

According to the World Report on disability among those individuals aged 0-14 years of age, $5.1 \%$ had severe or moderate disabilities and $0.7 \%$ severe disabilities, or 93 million and 13 million children, respectively. Among those with 15 years of age or more, figures were $19.4 \%$ and $3.8 \%$, or 892 million and 175 million, respectively [6].

Hearing is the bilateral loss, partial or total loss, of forty-one decibels $(\mathrm{dB})$ or more, as measured by an audiogram in the frequencies of $500 \mathrm{~Hz}, 1000$ $\mathrm{Hz}, 2000 \mathrm{~Hz}$ and $3000 \mathrm{~Hz}$. Visual impairment is classified as blindness when visual acuity equal to or less than 0.05 in the better eye with the best optical correction; low vision is when visual acuity is between 0.3 and 0.05 in the better eye with the best optical correction; moreover, cases in which the sum of the measurements of visual field in both eyes is equal to or smaller than $60^{\circ}$; or the simultaneous occurrence of any of the above conditions. Physical disability is the complete or partial change of one or more segments of the human body, leading to impaired physical functioning, appearing in the form of paraplegia, paraparesis, monoplegia, monoparesis, quadriplegia, tetraparesis, triplegia, triparesia, hemiplegia, hemiparesis, ostomy, amputation or absence of member, cerebral palsy, dwarfism, members with congenital or acquired deformities, except cosmetic deformities and those that do not cause difficulties for the performance of duties [7].

Therefore, the objective was to gather information about deficiency in adolescents in a mediumsized municipality and correlate it with demographic data, thereby subsidizing social and health policies and provide conditions for the most reliable protection to the real needs of the affected and their families.

\section{Methods}

This is a transversal and quantitative study in a medium-sized municipality. Respondents were all teenagers between 10 and 19 years with hearing, visual and physical disabilities, identified by community health workers in their areas of coverage.

Data collection was performed by interview with a questionnaire containing sociodemographic characteristics, being: gender, age, race, years of education and origin; type, cause and degree of disability. Questionnaires were administered during home visits by previously trained community health agents [8].

Data was organized in Excel 2010 spreadsheets and processed in Statistical Package for Social Sciences version 20.0 software. Associations between physical, visual and hearing impairments and other variables were carried out through the Chi-square test. Statistical significance was verified by a 0.05 level. The study respected international ethical principles in research with humans.

\section{Results}

102 adolescents with disabilities were identified. Table 1 presents the types of disabilities and sociodemographic characteristics and Table 2 by type of disability. 
Table 1. Distribution of the number of teenagers, according to sociodemographic characteristics

\begin{tabular}{|c|c|c|c|c|}
\hline \multirow{2}{*}{ Sociodemographic characteristics } & Physical Impairment & Hearing Impairment & Visual Impairment & \multirow{2}{*}{ p } \\
\hline & n ( \%) & $\mathrm{n}(\%)$ & $\mathrm{n}(\%)$ & \\
\hline \multicolumn{4}{|l|}{ Gender } & \multirow{3}{*}{$0.415^{1}$} \\
\hline Male & $36(52.9)$ & $8(11.8)$ & $24(35.3)$ & \\
\hline Female & $17(50.0)$ & $8(23.5)$ & $9(26.5)$ & \\
\hline \multicolumn{4}{|l|}{ Age (years) } & \multirow{3}{*}{$0.185^{1}$} \\
\hline $10-14$ & $29(53.7)$ & $5(9.3)$ & $20(37.0)$ & \\
\hline $15-19$ & $24(50.0)$ & $11(22.9)$ & $13(24.1)$ & \\
\hline \multicolumn{4}{|l|}{ Skin } & \multirow{3}{*}{$0.080^{1}$} \\
\hline White & $18(72.0)$ & $2(8.0)$ & $5(20.0)$ & \\
\hline Black/Mulatto & $35(45.4)$ & $14(18.2)$ & $28(36.4)$ & \\
\hline \multicolumn{4}{|l|}{ Education (years) } & \multirow{5}{*}{$0.023^{2}$} \\
\hline None & $31(68.9)$ & $3(6.7)$ & $11(24.4)$ & \\
\hline 1 to 4 & $8(28.6)$ & $6(21.4)$ & $14(50.0)$ & \\
\hline 5 to 9 & $10(55.6)$ & $4(22.2)$ & $4(22.2)$ & \\
\hline Secondary & $4(36.4)$ & $3(27.2)$ & $4(36.4)$ & \\
\hline \multicolumn{4}{|l|}{ Origin } & \multirow{3}{*}{$0.208^{1}$} \\
\hline Urban region & $28(60.9)$ & $7(15.2)$ & $11(23.9)$ & \\
\hline Rural region & $25(44.6)$ & $9(16.1)$ & $22(39.3)$ & \\
\hline
\end{tabular}

Table 2. Distribution of the number of teenagers, according to disability characteristics

\begin{tabular}{|c|c|c|c|c|}
\hline \multirow{2}{*}{ Characteristics of disability } & Physical Impairment & Hearing Impairment & Visual Impairment & \multirow{2}{*}{$p$} \\
\hline & $n(\%)$ & $\mathrm{n}(\%)$ & $\mathrm{n}(\%)$ & \\
\hline \multicolumn{4}{|l|}{ Level } & \multirow{3}{*}{$0.675^{1}$} \\
\hline Total & $26(49.1)$ & $10(18.9)$ & $17(32.0)$ & \\
\hline Partial & $27(55.1)$ & $6(12.3)$ & $16(32.6)$ & \\
\hline \multicolumn{4}{|l|}{ Cause } & \multirow{4}{*}{$0.090^{2}$} \\
\hline Congenital & $43(61.4)$ & $9(12.9)$ & $18(25.7)$ & \\
\hline Accident & $6(33.3)$ & $3(16.7)$ & $9(50.0)$ & \\
\hline Prior Complications & $4(28.6)$ & $4(28.6)$ & $6(42.8)$ & \\
\hline
\end{tabular}




\section{Discussion}

In the investigated group, there was a predominance of male adolescents living with physical disabilities, followed by visual and auditory. Among 102 college students where 51 were disabled, (45.1\%) were registered as having a physical disability, followed by hearing (33.3\%) and visual (21.6\%) [9]. Mueller-Johnson, Eisner et al. [10] in a sample of 6,649 adolescents in Swiss schools, 360 (5.1\%) were identified with physical disabilities.

In the analyzed disabilities, physical predominated among those who were black or mulatto $(72.0 \%)$ and there was no statistical significance presented between disabilities in the study $(p=0.080)$. In another study where 8,326 people were assessed in a cross-sectional research, there were no differences between color/race [11].

An association was found in the sociodemographic characteristics only between disability and level of education ( $p=0.023$ ). Among those who were disabled, illiteracy predominated, while the hearing and visually impaired had schooling between one and four years of study. Therefore, these data were surprising, as visually and hearing impaired children require special conditions of education to be literate, with experienced teachers in Braille or sign language, so apparently more complex demands are being met than those imposed by physical barriers.

A study of 123 patients with disabilities reported that half had no schooling, a small portion reached high school (11.4\%) and held no university degree [5]. Freire, Gigante et al. [12] however, in a study of 1,842 deaf people of at least 15 years old, education was 11 years or more (33.7\%), with $96.4 \%$ being literate, although without specification of the language by the authors.

Parents of children and adolescents with disabilities considered it difficult to obtain enrollment for their children, with the greatest difficulties being related to the acceptance of the child by the school [13]. Shandra, Avery et al. [14] poverty, inadequate housing and low education levels in adults were twice as likely - and unemployment of an adult five times more likely - in families with several members with disabilities compared to families without disabilities.

There was a level of total or partial disability adopted in this study, and there was no significance to the type of disability $(p=0.675)$. However, in the cause, despite the association with type not being statistically significant ( $p=0.90$ ), the highest percentage of congenital/genital defects was among the physically disabled. It is known that lack of assistance in pregnancy is a major cause of disability, and poor prenatal care is responsible for $16.8 \%$ of cases, followed by those which are the result of genetic defects being responsible for 16.6\% [15].

In a study of 8,974 newborns, 17 had hearing impairment, $(64.7 \%)$ of these with probable etiology prenatal causes, and (36.4\%) confirmed genetic origin or (36.4\%) presumed heritability [16]. There is evidence that unhealthy eating habits and physical inactivity, which lead to obesity, also substantially contribute to the global burden of disease, death and disability [17-20], Khandaker G, Muhit et al. [21] as well as infectious diseases.

For the visually impaired, the highest percentages were those caused by accidents (47.0\%) and complications from previous diseases (42.8\%). It is estimated that about 950,000 deaths are due to external causes among children under 18 years of age every year, and over 10 million from impairments [22].

Disabled adolescents are exposed to additional risks to their physical integrity and health. Some reports warn that high school students with disabilities are more likely to be victims of violence compared to those without disabilities [23], and high school girls from this experience are more likely to suffer mental health damage and use drugs [24]. Denny, Silva et al. [25] this vulnerability is evident in a New Zealand study that evaluated 9,107 students aged 9-13 years, of which $18 \%$ in the sample were living with chronic illness or disability; they had high levels of depressive symptoms and recognized the 
impact of illness or disability on their everyday activities (18\%) and socialization skills (40\%).

\section{Conclusions}

Physical disability had the highest prevalence, followed by visual and auditory impairments, respectively. There was statistical correlation between the type of disability and the level of education, and this correlation is also evidenced in the literature. Most of the illiterate and more than half of those between five and ten years of study have physical disabilities; while exactly half of those with one to four years of schooling have visual impairment. Black and brown color skin are more associated with physical and hearing impairments, while visual impairment was evenly distributed between the two categories. The highest percentage of congenital causes was found among the physically disabled. Among those with visual impairment, accidents and complications from diseases were the main causes.

Therefore, despite the implementation of public policies for prevention of disability, they are very weak in facing the real demand that the problem requires. Also, due to the complexity of the sample, it requires physical and technical organization associated with political effort to fulfill the strategies by responsible institutions/organizations.

\section{Acknowledgements}

Conselho Nacional de Desenvolvimento Científico e Tecnológico (grant number 562762/2008-6), for their financial support.

\section{References}

1. Bezerra $C P$, Pagliuca LMF, Galvão MTG. Nursing model based on activities of daily living: a diabetic and visually-impaired adolescent. Esc Anna Nery. [Internet]. 2009 [cited 2015 nov 04]; 13: 842-8. Available from: http://www.scielo.br/pdf/ean/v13n4/ v13n4a21.pdf

2. World Health Organization (WHO). Health topics: adolescent health. Geneva: WHO; [Internet]. 2010. [cited 2015 nov 04]; Available from: http://www.who.int/topics/adolescent health/en/

3. Aragão AKR, Sousa $A$, Silva $K$, et al. Accessibility of disabled children and adolescents to basic oral health attention at the public health system - a pilot study. Pesq Bras Odontoped Clin Integr [Internet]. 2011 [cited 2015 nov 04]; 11: 159-64. Available from: http://revista.uepb.edu.br/index.php/pboci/article/view/1425

4. Machado WCA, Scramin AP. Functional (in)dependence in the dependent relationship of quadriplegic men with their (un)replaceable parents/caregivers. Rev Esc Enferm USP [Internet]. 2010 [cited 2015 nov 04]; 44: 53-60. Available from: http://www.scielo.br/pdf/reeusp/v44n1/en a08v44n1.pdf

5. Santos S, Pequeno AAS, Galvão CRC, et al. The causes of physical disability in municipalities of the northeast of Brazil and an estimate of costs of specialized services. Ciênc Saúde Coletiva [Internet]. 2014 [cited 2015 nov 04]; 19: 559-68. Available from: http://www.scielo.br/pdf/csc/v19n2/1413-8123csc-19-02-00559.pdf

6. World Health Organization (WHO). World report on disability. Geneva: WHO; [Internet]. 2011 [cited 2015 Aug 27]. Available from: http://www.pessoacomdeficiencia.sp.gov.br/usr/share/ documents/RELATORIO MUNDIAL COMPLETO.pdf

7. World Health Organization (WHO). International Classification of Functioning, Disability and Health. Geneva: WHO; [Internet]. 2014 [cited 2015 aug 27]. Available from: http://www.who.int/ classifications/icf/en/\#

8. Maia ER, Pagliuca LMF, Almeida PC. Learning of community health agent to identify and register disabled people. Acta Paul Enferm [Internet]. 2014 [cited 2015 aug 27]. 27: 326-32. Available from: http://www.scielo.br/pdf/ape/v27n4/en 19820194-ape-027-004-0326.pdf

9. Sánchez MTP, López-Justicia MP. Autoconcepto de Estudiantes universitários com descapacidad visual, auditiva y motora. Rev Latinoam Psicol [Internet]. 2012 [cited 2015 aug 27]; 44: 87-98. Available from: http://www.redalyc.org/articulo. oa?id=80524058007

10. Mueller-Johnson K, Eisner MP, Obsuth I. Sexual victimization of youth with a physical disability an examination of prevalence rates, and risk and protective factors. J Interpers Violence [Internet]. 2014 [cited 2015 aug 27]; 29: 3180-206. Available from: http://jiv.sagepub.com/content/29/17/3180.long 
11. Castro SS, César CLG, Carandina L, et al. Visual, hearing, and physical disability: prevalence and associated factors in a population-based study. Cad Saúde Pública [Internet]. 2008 [cited 2015 aug 27]; 24: 1773-8. Available from: http://www. scielo.br/pdf/csp/v24n8/06.pdf

12. Freire DB, Gigante LP, Béria JU, et al. Access by hearing-disabled individuals to health services in a southern Brazilian city. Cad Saúde Pública [Internet]. 2009 [cited 2015 nov 27]; 25: 889-97. Available from: http://www.scielosp.org/pdf/csp/v25n4/20.pdf

13. Elias MP, Monteiro LMC, Chaves CR. Accessibility of legal benefits available in Rio de Janeiro for physically handicapped people. Ciênc Saúde Coletiva [Internet]. 2008 [cited 2015 oct 27]; 13: 1041-50. Available from: http://www.scielo.br/pdf/ csc/v13n3/27.pdf

14. Shandra CL, Avery RC, Hogan DP, et al. Child and adult disability in the 2000 Census: disability is a household affair. Disabil Health J [Internet]. 2012 [cited 2015 nov 27]; 5: 241-8. Available from: http://www.sciencedirect.com/science/ article/pii/S1936657412000908

15. Campos ECS, Mileski AV. The organization of the politics of health of the person with deficiency in the state of Paraná. Emancipação [Internet]. 2013 [cited 2015 aug 27]; 13: 169-81. Available from: http://www.revistas2.uepg.br/index.php/emancipacao/article/ view/3268

16. Pereira T, Costa KC, Pomilio MCA, et al. Etiological investigation of deaf in neonates screened in a universal newborn hearing screening program. Rev CEFAC [Internet]. 2014 [cited 2015 nov 16]; 16: 422-9. Available from: http://www.scielo.br/scielo. php?script=sci arttext\&pid=S1516-18462014000200422

17. Ng K, Rintala P, Tynjälä J, et al. Physical activity patterns of adolescents with long term illnesses or disabilities in finnish general education. European J Adapted Phys Activity [Internet]. 2014 [cited 2015 oct 26]; 7: 58-72. Available from: http://eujapa. upol.cz/index.php/EUJAPA/article/view/129/59

18. Yamaki K, Lowry BD, Buscaj E, et al. Availability of state-based obesity surveillance data on high school students with disabilities in the United States. Matern Child Health J [Internet]. 2015 [cited 2015 aug 27]; 19: 1152-61. Available from: http://link.springer. com/article/10.1007/s10995-014-1616-7

19. Grondhuis SN, Aman MG. Overweight and obesity in youth with developmental disabilities: A call to action. J Intellec Disabil Res [Internet]. 2013 [cited 2015 oct 22];58: 787-99. Available from: http://onlinelibrary.wiley.com/doi/10.1111/jir.12090/pdf

20. McGillivray J, McVilly K, Skouteris $H$, et al. Parental factors associated with obesity in children with disability: A systematic review. Obes Rev [Internet]. 2013 [cited 2015 nov 10]; 14: 54154. Available from: http://onlinelibrary.wiley.com/doi/10.1111/ obr.12031/pdf
21. Khandaker $G$, Muhit $M$, Rashid $H$, et al. Infections causes of childhood disability: results from a pilot study in rural Bangladesh. Trop Pediatr [Internet]. 2014 [cited 2015 aug 27]; 60: 363-9. Available from: http://www.ncbi.nlm.nih.gov/ pubmed/24929076

22. World Health Organization (WHO). World Report on child injury prevention. Geneva: WHO; 2008.

23. Mitra M, Mouradian VE, McKenna M. Dating violence and associated health risks among high school students with disabilities. Matern Child Health J [Internet]. 2013 [cited 2015 nov 10]; 17: 1088-94. Available from: http://link.springer.com/ article/10.1007\%2Fs10995-012-1091-y

24. Tunner HA, Vanderminden J, Finkelhor D, et al. Disability and victimization in a national sample of children and youth. Child Maltreat [Internet]. 2011 [cited 2015 aug 27]; 16: 275-86. Available from: http://cmx.sagepub.com/content/16/4/275.long

25. Denny S, Silva $M$, Fleming $T$, et al. The prevalence of chronic health conditions impacting on daily functioning and the association with emotional well-being among a national sample of high school students. J Adolesc Health [Internet]. 2014 [cited 2015 aug 23]; 54: 410-5. Available from: http://www.jahonline. org/article/S1054-139X\%2813\%2900506-5/pdf

\section{Publish in International Archives of Medicine}

International Archives of Medicine is an open access journal publishing articles encompassing all aspects of medical science and clinical practice. IAM is considered a megajournal with independent sections on all areas of medicine. IAM is a really international journal with authors and board members from all around the world. The journal is widely indexed and classified Q1 in category Medicine. 